\title{
Pembelajaran On-Line : Pengunaan Media Pembelajaran Audio Visual Berbasis Digital terhadap Penguasaan Ge rak Dasar Lay Up
}

\author{
Online Learning: The Use of Digital-Based Audio Visual Learning Media for \\ Basic Motion Mastery Lay Up
}

\author{
Dindin Bernhardin ${ }^{1}$, Alghifari Rizkia Rahmani ${ }^{2}$ \\ ${ }^{1,2}$ Program studi PJKR, STKIP Pasundan, Cimahi, Jawa Barat, 40512, Indonesia
}

\begin{abstract}
Abstrak
Tujuan penelitian ini bertujuan untuk mengetahui dampak dari penggunaan media pembelajaran audio-visual berbasis digital terhadap penguasaan gerak dasar lay up pada pembelajaran penjas materi bola basket. Penelitian ini menggunakan metode penelitian expost facto. Populasi dalam penelitian ini adalah siswa kelas X IPA 1,2,3,4 dan 5 di SMAN 1 Wanayasa yang berjumlah 166 orang siswa. Teknik pengambilan sampel dalam penelitian ini menggunakan simple random sampling dengan sampel penelitian berjumlah 33 siswa. Instrument tes yang digunakan dalam penelitian ini adalah tes keterampilan gerak dasar lay up. Analisis data dengan cara statistik deskriptif dengan perhitungan persentase. Hasil penelitian menunjukkan bahw a secara rata-rata penguasaangerak dasar lay up sisw a berada pada kategori baik. Sehingga dapat diperoleh oleh kesimpulan bahwa media pembelajaran audio-visual berbasi digital memiliki dampak positif pada hasil pembelajaran gerak dasar lay up.
\end{abstract}

Kata kunci : media pembelajaran, audio-visual, gerak dasar lay up.

\begin{abstract}
The aim of this study was to determine the effect of the use of digital-based audio-visual learning media on the mastery of basic motion lay-ups in physical education learning in basketball material. This research uses ex post facto research method. The population in this study were students of class X IPA 1,2,3,4 and 5 at SMAN 1 Wanayasa, totaling 166 students. The sampling technique in this study used simple random sampling with a sample of 33 students. The test instrument used in this study was the lay-up basic motion skill test. Data analysis by means of descriptive statistics by calculating the percentage. The results showed that on average, the basic character of the students' lay-up was in the good category. So it can be obtained by the conclusion that digital-based audio-visual learning media has a positive impact on the results of learning basic motion layouts.

Keywords : instructional media, audio-visual, basic motion lay-up.
\end{abstract}

\section{PENDAHULUAN}

Pendidikan jasmani merupakan suatu proses pendidikan melalui aktivitas jasmani yang bertujuan untuk meningkatkan kebugaran jasmani, mengembangkan ketrampilan motorik, sikap sportif, kecerdasan emosial, pengetahuan serta perilaku hidup sehat dan 
aktif (sumbodo pp, 2016). Pendidikan jasmani tidak akan mencapai tujuan tanpa adanya rencana yang matang dalam proses pembelajaranya. Berkaitan dengan proses pembelajaran maka perlu adanya pendekatan, strategi, dan model pembelajaran yang tepat didalam proses pembelajaran Pendidikan Jasmani (Budiman et al., 2018).

Model pembelajaran dapat ditentukan oleh guru atau dosen dengan memperhatikan tujuan dan materi pembelajaran yang akan diajarkan merujuk pada situasi dan kondisi yang terjadi di sekolah. Model pembelajaran yang terbaik adalah yang paling sesuai dengan karakteristik peserta didik, tujuan, materi ajar, alat/media, waktu yang tersedia, situasi dan kondisi (Budiman, 2017).

Namun tantangan baru hadir bagi para guru penjas di era saat ini, dimana dengan situasi yang merebak yang mengancam kesehatan seluruh tatanan masyarakat yaitu merebaknya virus Covid-19 (Hammami et al., 2020; Jauhari et al., 2020; Law anson et al., 2020), mengharuskan seluruh tenaga pengajar, tidak tekecuali guu penjas untuk melakukan pembelajaran secara daring. Hal ini sesuai dengan surat edaran Kementerian Pendidikan dan Kebudayaan (Kemendikbud) No. 4 tahun 2020 tentang pelaksanaan kebijakan pendidikan dalam masa darurat penyebaran Coronavirus Disesase (Covid-19) terkait proses belajar menyatakan bahwa belajar dari rumah melalui pembelajaran daring/jarak jauh dilaksankan untuk memberikan pembelajaran yang bermakna bagi siswa.

Pembelajaran daring merupakan pembelajaran yang memanfaatkan teknologi multimedia, video, kelas virtual, teks online animasi, pesan suara, email, telepon konferensi, dan video steraming online. Pembelajaran dapat dilakukan secara masif dengan jumlah peserta yang tidak terbatas, bisa dilakukan secara gratis maupun berbayar. Hal ini dilakukan untuk menghindari kontak langsung antara pendidik dan peserta didik yang mana sistem pembelajaran secara kovensional atau tatap muka dapat memperluas penyebaran virus covid-19 (Firman \& Rahayu, 2020).

Namun pembelajaran melalui daring ini memiliki beberapa kendala seperti susahnya sinyal untuk mengakses pembelajaran tersebut, kurangnya pemahaman siswasiswa dengan pembelajaran melalui daring sehingga mempengaruhi pemahaman belajar siswa dalam mengikuti proses pembelajaran pendidikan jasmani (Firman \& Rahayu, 2020). Seharusnya sebuah model pembelajaran itu harus mempermudahkan siswa untuk terlibat dalam proses pembelajaran dan mampu memahami materi pembelajaran yang disampaikan.

Dalam pembelajaran daring memiliki beberapa bentuk yang terdapat di dalam aplikasi yang bisa diakses oleh siswa yaitu whatsapp, classroom, zoom meeting, dan 
google meet. Akan tetapi tidak semua bentuk pembelajaran daring tersebut dapat digunakan atau dipahami oleh siswa, kemudian peneliti melihat metode pembelajaran yang bisa dipahami oleh siswa dengan media pembelajaran audio-visual (Bastomi \& Hartoto, 2018; Haryoko, 2009).

Terkait dengan materi pembelajaran (bahan ajar), khususnya dalam bentuk permainan dan olahraga, banyak sekali jenis-jenis permainan yang harus diajarkan kepada siswa. Salah satunya adalah permainan bola basket yang termasuk ke dalam kelompok permainan bola besar (Dedi, 2016). Pembelajaran bola basket dapat menyalurkan hobi, bakat dan kegembiraan siswa, selain itu dapat membuat siswa akan lebih bugar kondisi tubuhnya. Berbicara tentang permainan bola basket, bola basket adalah suatu permainan yang dimainkan oleh dua regu yang masing-masing terdiri dari lima orang.

Sesuai dengan kurikulum mata pelajaran pendidikan jasmani, bola basket adalah salah satu materi yang diberikan dan dikenalkan yang sama hal nya dengan materi yang lain, ada beberapa faktor yang menentukan terhadap berhasilnya belajar siswa dalam mengikuti olahraga, yaitu faktor internal dan faktor eksternal yang dimiliki oleh masingmasing siswa. faktor internal seperti ; bakat, minat, motivasi, dan intelegensi (Astuti, 2015). Selain itu faktor eksternal atau faktor yang berasal dari luar seperti seperti guru/ pelatih, waktu latihan, adanya sarana dan prasarana (Bajuri, 2016).

Dalam kaitan ini peneliti ingin megetahui permasalahan proses pembelajaran dalam pembelajaran jarak jauh (daring), hal ini dikarenakan proses pembelajaran tatap muka belum bisa dilaksanakan. Kondisi tersebut mendorong penulis untuk melakukan kajian terhadap pemahaman siswa pada pembelajaran jarak jauh (daring) dalam pembelajaran pendidikan jasmani khususnya pembelajaran bola basket dengan materi gerak dasar teknik lay up.

\section{METODE}

Metode penelitian yang digunakan penulis dalam penelitian ini dengan melihat pertimbangan yang ada adalah dengan metode penelitian Deskriptif Expost Facto (Fraenkel \& Wallen, 2008). Penelitian expost facto merupakan penelitian yang bertujuan menemukan penyebab yang memungkinkan perubahan perilaku, gejala atau fenomena yang disebabkan oleh suatu peristiwa, perilaku atau hal-hal yang menyebabkan perubahan pada variable bebas yang secara keseluruhan sudah terjadi (Widarto, 2013).

Populasi dalam penelitian ini adalah siswa kelas X IPA 1,2,3,4 dan 5 di SMAN 1 Wanayasa yang berjumlah 166 orang siswa. Pemilihan sampel menggunakan teknik simple random sampling, sehingga terpilih 33 orang siswa sebagai sampel penelitian. 
Instrumen yang digunakan adalah instrument tes keterampilan gerak lay up yang peneliti kembangkan dan memiliki tingkat reliabilitas 0,735. Sedangkan untuk teknis pelaksanaannya, sampel penelitian melakukan gerakan lay up yang kemudian mereka dokumentasikan yang mana dokumen tersebut menjadi acuap penilaian. Dalam penelitian ini teknik pengelolaan dan analisis data yang digunakan adalah dengan menghitung persentase gambaran perolehan nilai yang diberikan oleh peneliti sesuai dengan kriteria penskoran.

\section{HASIL DAN PEMBAHASAN}

Hasil

Berikut ini adalah hasil persentase indicator penilaian gerak lay up siswa. Hasil tersebut dapat dilihat pada table 1 di baw ah ini:

Tabel 1. Hasil Persentase Berdasarkan Indikator Gerak Lay Up

\begin{tabular}{|c|c|c|c|c|}
\hline $\begin{array}{c}\text { Variabel } \\
\text { Penelitian }\end{array}$ & $\begin{array}{l}\text { Sub Variabel } \\
\text { Penelitian }\end{array}$ & Indikator Gerak & $\begin{array}{c}\text { Persentase } \\
\%\end{array}$ & $\begin{array}{c}\text { Tingkat } \\
\text { Keberhasilan } \\
\text { Belajar }\end{array}$ \\
\hline \multirow[t]{11}{*}{$\begin{array}{l}\text { Gerak Dasar } \\
\text { Lay Up }\end{array}$} & $\begin{array}{l}\text { Sikap A walan/ } \\
\text { Persiapan }\end{array}$ & $\begin{array}{l}\text { Langkah pertama setelah } \\
\text { dribbling (memantulkan } \\
\text { bola) menyesuaikan dengan } \\
\text { jarak ring, memperhitungkan } \\
\text { langkah kedua }\end{array}$ & 70 & Baik \\
\hline & & $\begin{array}{l}\text { 2. langkah kedua pendek untuk } \\
\text { memperoleh awalan tolakan } \\
\text { yang kuat agar dapat } \\
\text { melompat yang tinggi }\end{array}$ & 61 & Baik \\
\hline & & $\begin{array}{l}\text { 3. Gerakan lengan rileks dan } \\
\text { menguasai bola }\end{array}$ & 85 & Baik Sekali \\
\hline & & $\begin{array}{l}\text { 4. tangan yang tidak menembak } \\
\text { diletakkan dibawah bola }\end{array}$ & 73 & Baik \\
\hline & & $\begin{array}{l}\text { 5. tangan yang menembak } \\
\text { diletakkan di belakang bola }\end{array}$ & 79 & Baik Sekali \\
\hline & & 6. Tangan stabil memegang bola & 72 & Baik \\
\hline & $\begin{array}{l}\text { Sikap } \\
\text { Pelaksanaan }\end{array}$ & $\begin{array}{l}\text { 1. angkat lutut untuk melompat } \\
\text { ke arah vertical }\end{array}$ & 70 & Baik \\
\hline & & $\begin{array}{l}\text { 2. tangan yang menembak } \\
\text { diangkat lurus ke atas, }\end{array}$ & 77 & Baik Sekali \\
\hline & & $\begin{array}{l}\text { 3. bola dilepas dengan kekuatan } \\
\text { ujung jari pada titik tertinggi } \\
\text { dan memantul } \\
\text { disekitar garis tegak sebelah } \\
\text { kanan pada petak kecil di } \\
\text { atas keranjang, jika } \\
\text { dilakukan dari sisi kanan. }\end{array}$ & 82 & Baik Sekali \\
\hline & $\begin{array}{l}\text { Sikap Akhir I } \\
\text { follow through }\end{array}$ & $\begin{array}{l}\text { 1. mendarat dengan seimbang } \\
\text { dan lutut ditekuk }\end{array}$ & 78 & Baik Sekali \\
\hline & & $\begin{array}{l}\text { 2. Lengan rileks (keatas atau di } \\
\text { bawah) }\end{array}$ & 71 & Baik \\
\hline
\end{tabular}


Berdasarkan tabel diatas tentang persentase indikator gerak lay up diperoleh skor penilaian sebesar 1079 dari 11 indikator penilaian, yang terbagi atas Langkah pertama setelah dribbling (memantulkan bola) menyesuaikan dengan jarak ring mendapat persentase sebesar 70\% dengan kriteria Baik; langkah kedua langkah kedua pendek untuk memperoleh awalan tolakan yang kuat agar dapat melompat yang tinggi mendapat persentase sebesar $61 \%$ dengan kriteria Baik; Gerakan lengan rileks dan menguasai bola mendapat persentase sebesar $85 \%$ dengan kriteria Baik Sekali; tangan yang tidak menembak diletakkan dibawah bola mendapatkan persentase sebesar 73\% dengan kriteria Baik; tangan yang menembak diletakkan di belakang bola mendapat persentase sebesar 79\% dengan kriteria Baik Sekali; Tangan stabil memegang bola mendapat persentase sebesar 72\% dengan kriteria Baik; angkat lutut untuk melompat ke arah vertikal mendapat persentase sebesar $70 \%$ dengan kriteria Baik; tangan yang menembak diangkat lurus ke atas mendapat persentase sebesar 77\% dengan kriteria Baik Sekali; bola dilepas dengan kekuatan ujung jari pada titik tertinggi dan memantul disekitar garis tegak sebelah kanan pada petak kecil di atas keranjang jika dilakukan dari sisi kanan mendapat persentase sebesar $82 \%$ dengan kriteria Baik Sekali; mendarat dengan seimbang dan lutut ditekuk mendapat persentase sebesar 78\% dengan kriteria Baik Sekali; dan Lengan rileks (keatas atau di baw ah) mendapat persentase sebesar $71 \%$ dengan kriteria Baik.

\section{Pembahasan}

Pencapaian keberhasilan belajar gerak dasar lay up dengan persentase beragam yang rata-rata tingkat kriterianya baik dihubungkan dengan penggunaan media audio visual bisa dikatakan cukup berhasil walaupun tidak maksimal seperti pembelajaran langsung, karena karakteristik media audio visual bersifat mencontoh saja tidak ada kontrol dan koreksi dari guru (Bastomi \& Hartoto, 2018). Kemudian pada sisi siswa yang menggunakan media audio visual sangatlah beragam tergantung dari motivasi siswa itu sendiri yang bisa dinilai oleh guru bisa dikatakan seadanya saja, dan pembelajarannya pun sesuai keinginan siswa itu sendiri (Andriani \& Rasto, 2019; Ginanjar, 2016), disisi lain perangkat yang digunakan sangat beragam dari mulai gadget yang digunakan sampai ketersediaan sinyal.

Sedangkan hasil belajar yang telah dilakukan kaitannya dengan materi yang telah dipelajari dalam hal ini gerak dasar lay up mudah dipahami karena tahapan gerak lay up tidak begitu rumit apabila sarana yang ada dirumah memadai.

Maksimal tidaknya hasil belajar memanglah sangat tergantung pada pengemasan dan penyampaian materi yang guru berikan. Terlebih sebuah tantangan besar saat ini 
dimana pembelajaran harus dilaksanakan secara online atau daring, yang mana pembelajaran online itu tidak hanya memberikan dampak yang positif bagi pembelajaran seperti bertambahnya kemampuan guru dalam melaksanakan pembelajaran yang seirama dengan kemajuan teknologi, melainkan ada efek negative juga yang perlu diperhatikan.

\section{KESIMPULAN}

Masa Pandemi Covid-19 memang sudah tidak bisa dihindari. Semakin meningkatnya kasus masyarakat yang terdampak virus yang berimbas terhadap pembataan kegiatan social termasuk pembelajaran normal tatap muka. Hal ini menuntut guru untuk berfikir keras dalam melaksanakan Kegiatan Belajar Mengajar dan penerapan media audio visual merupakan salah satu metode pembelajaran yang dirokemdasikan untuk mengatasi situasi sekarang ini. Dimana melalui metode seperti ini bisa mudah dimengerti oleh siswa dan bisa meningkatkan minat serta motivasi siswa yang akan berimbas pada hasil belajar mereka, seperti hasil belajar lay up bola basket pada penelitian ini.

\section{DAFTAR PUSTAKA}

Andriani, R., \& Rasto, R. (2019). Motivasi belajar sebagai determinan hasil belajar siswa. Jurnal Pendidikan Manajemen Perkantoran, 4(1), 80. https://doi.org/10.17509/jpm.v4i1.14958

Astuti, S. P. (2015). Pengaruh Kemampuan Awal dan Minat Belajar terhadap Prestasi Belajar Fisika. Formatif: Jurnal Ilmiah Pendidikan MIPA, 5(1), 68-75. https://doi.org/10.30998/formatif.v5i1.167

Bajuri, P. E. (2016). Penerapan Alat Bantu Pembelajaran Untuk Meningkatkan Hasil Belajar Lompat Tinggi Gaya Straddle. Jurnal SPORTIF: Jurnal Penelitian Pembelajaran, 2(2), 67-75. https://doi.org/10.29407/js_unpgri.v2i2.484

Bastomi, M. R. \& Hartoto, S. (2018). Pengaruh Penerapan Media Audio Visual Terhadap Hasil Belajar Renang Gaya Dada. Jurnal Pendidikan Olahraga Dan Kesehatan, 6(1), 5-9.

Budiman, A. (2017). PENINGKATAN PERILAKU RESPEK DAN REGULASI DIRI SISWA MELALUI MODEL TPSR (TEACHING PERSONAL AND SOCIAL RESPONSIBILITY) DALAM PENDIDIKAN JASMANI. Universitas Pendidikan Indonesia.

Budiman, A., Juliantine, T., \& Abduljabar, B. (2018). Student's Low Respect and SelfRegulation: is TPSR the Solution. Integrating Science and Technology in Developing Sport and Physical Education. Portugal: SCITEPRES.

Dedi, K. (2016). KETERAMPILAN DRIBBLING BOLA BASKET. Jurnal Olahraga, 2(1), 1-8. 
Firman, F., \& Rahayu, S. (2020). Pembelajaran Online di Tengah Pandemi Covid-19. Indonesian Journal of Educational Science (IJES), 2(2), 81-89. https://doi.org/10.31605/ijes.v2i2.659

Fraenkel, J. R., \& Wallen, N. E. (2008). How to Design and Evaluate Research in Education (7th ed.). McGraw-Hill Higher Education.

Ginanjar, A. (2016). Hasil Belajar Pendidikan Jasmani: Disiplin Motivasi dan Percaya Diri. Jurnal MAENPO, VI, 88-96.

Hammami, A., Harrabi, B., Mohr, M., \& Krustrup, P. (2020). Physical activity and coronavirus disease 2019 (COVID-19): specific recommendations for home-based physical training. Managing Sport and Leisure, $0(0), \quad 1-6$. https://doi.org/10.1080/23750472.2020.1757494

Haryoko, S. (2009). Efektivitas Pemanfaatan Media Audio-Visual Sebagai Alternatif Optimalisasi Model Pembelajaran. Jurnal Edukasi, 5(1), 1-10.

Jauhari, M. N., Mambela, S., \& Zakiah, Z. (2020). Dampak Pandemi Covid-19 Terhapad Pelaksanaan Pembelajaran Penjas Adaptif Di Sekolah Luar Biasa. STAND : Journal Sports Teaching and Development, 1(1), 63-70. https://doi.org/10.36456/jstand.v1i1.2594

Law anson, T., Foley, L., Assah, F., Mogo, E., Mapa-Tassou, C., Ogunro, T., Onifade, V., \& Oni, T. (2020). The urban environment and leisure physical activity during the COVID-19 pandemic: a view from Lagos. Cities \& Health, OO(00), 1-4. https://doi.org/10.1080/23748834.2020.1806459 